\title{
腐食科学における一つのナノテクノロジー（その 4)
}

一共有結合で金属に吸着した自己組織化膜の化学修飾による保護皮膜の作製一

\author{
荒 牧 國 次*
}

* 慶應義塾大学名誉教授

\author{
A Nanotechnology in Corrosion Science (Part 4) \\ - Preparation of Protective Films by Chemical Modification of \\ Self-Assembled Monolayer Adsorbed on Metal via a Covalent Bond - \\ Kunitsugu Aramaki* \\ * Professor Emeritus, Keio University
}

\begin{abstract}
A self-assembled monolayer (SAM) of p-hydroxymethylbenzene moiety adsorbed on iron by the formation of a covalent bond between iron and carbon atoms was prepared by electrolytic reduction of diazonium ion. Ultrathin polymer films of the SAM were prepared on the iron surface by chemical modification with alkylethoxysilanes. The protective abilities of the films against iron corrosion were examined by polarization measurements in an aerated 0.5 $\mathrm{M} \mathrm{NaCl}$ solution. High protective performances of the films were obtained after immersion in the solution for many hours due to the formation of a strong adsorption bond.
\end{abstract}

Key words : ultrathin protective coatings, self-assembled monolayer, $p$-hydroxymethylbenzene, iron, covalent adsorption bond, chemical modification, polymer films

\section{1.はじめに}

「腐食抑制剂の作用（その 1）（その 2)」1，2）で述べた ように，金属あるいは酸化された金属表面に強い吸着単 分子皮膜を作るには化学吸着によって行われる．抑制剤 分子 $\mathrm{R}_{n} \mathrm{X}:(\mathrm{R}$ は非極性基， $n$ はその数， $\mathrm{X}$ は極性基，: は 非共有電子対）が金属 $[\mathrm{M}]$ （［］は表面の原子やイオンを 表している）に

$$
[\mathrm{M}]+\mathrm{R}_{n} \mathrm{X}: \rightarrow[\mathrm{M}]: \mathrm{XR}_{n}
$$

のように，抑制剤の非共有電子対を金属原子と極性基で 共有することで安定な結合（配位結合）を作る。これは 裸の金属表面で起こる吸着で, 裸の金属が軟らかい酸で あるために軟らかい塩基の抑制剂が安定な吸着結合を作 る（腐食抑制剤の作用と硬いおよび軟らかい酸塩基の法 則 (HSAB 則) 参照 $)^{3)}$-5)

酸素を含む中性や弱塩基性水溶液中に存在する金属表 面は酸化された表面であり，多価の金属イオンが存在す る.したがって，酸化された金属表面 $\left[\mathrm{M}^{n+} \mathrm{O}\right]$ に抑制剤は

$$
\left[\mathrm{M}^{n+} \mathrm{O}\right]+\mathrm{R}_{n} \mathrm{X}: \rightarrow\left[\mathrm{M}^{n+} \mathrm{O}\right]: \mathrm{XR}_{n}
$$

のように，化学吸着あるいは錯体の沈殿皮膜を作る（腐 食抑制剂の作用 (その 2$)$ ，(その 3 $)^{6)}$ 参照)。この場合は $\mathrm{M}^{n+}$ が硬い酸であるために硬い塩基の抑制剤が使われる. このような吸着単分子膜は十分にち密で規則正しい配列 をしていて，自己組織化膜と呼んでいる.

たとえば，11-メルカプト-1-ウンデカノール $\mathrm{HO}\left(\mathrm{CH}_{2}\right)_{11} \mathrm{SH}$ （略号 MUO）は $\mathrm{Cu}$ 表面にち密で規則正 しい配列をした自己組織化膜を作る.

$$
[\mathrm{Cu}]+\mathrm{HO}\left(\mathrm{CH}_{2}\right)_{11} \mathrm{SH} \rightarrow[\mathrm{Cu}] \mathrm{S}\left(\mathrm{CH}_{2}\right)_{11} \mathrm{OH}+\mathrm{H}^{+}+\mathrm{e}^{-}
$$

酸素を含む $0.5 \mathrm{M} \mathrm{Na}_{2} \mathrm{SO}_{4}$ 中におけるこの皮膜で覆った $\mathrm{Cu}$ 電極の分極測定から腐食防止率 $P(\%)$ を

$$
P(\%)=100\left(1-i_{\text {cor }} / i_{\text {cor }}{ }^{0}\right)
$$

$\left(i_{\mathrm{cor}}{ }^{0}, i_{\mathrm{cor}}\right.$ は裸と皮膜で覆った電極の腐食電流密度）から 求めると，あまり高い值は得られない。そこでこの皮膜 を化学修飾（表面で化学反応させること）して，一次元

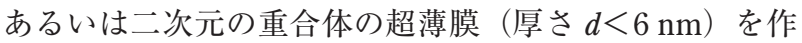
製すると， $0.5 \mathrm{M} \mathrm{Na}_{2} \mathrm{SO}_{4}$ 中における $\mathrm{Cu}$ の腐食をほぼ完 全に防止し $(P=99.3 \%)$ ，また室内大気腐食に対しても 非常に優れた防止効果が認められた（腐食科学における

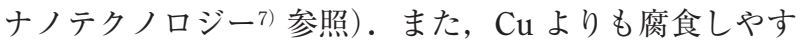
い $\mathrm{Fe}$ 上に同様な超薄重合膜を作製したが， $\mathrm{Cu}$ 上ほど高 い防止効果は得られなかった（腐食科学におけるナノテ クノロジー (つづき $\left.)^{8)}\right)$.

不動態皮膜で覆った $\mathrm{Fe}$ 表面 $[\mathrm{FeO}] \mathrm{OH}$ 上に 16 -ヒドロ キシヘキサデカン酸イオン $\mathrm{HO}\left(\mathrm{CH}_{2}\right){ }_{15} \mathrm{CO}_{2}{ }^{-}\left(\mathrm{HOC}_{16} \mathrm{~A}^{-}\right)$ の自己組織化膜を作製する.

$[\mathrm{FeO}] \mathrm{OH}+\mathrm{HO}\left(\mathrm{CH}_{2}\right)_{15} \mathrm{CO}_{2}$

$$
\rightarrow[\mathrm{FeO}] \mathrm{O}_{2} \mathrm{C}\left(\mathrm{CH}_{2}\right)_{15} \mathrm{OH}+\mathrm{OH}^{-}
$$

不動態皮膜表面に存在する $\mathrm{Fe}^{3+}$ は硬い酸に属するので, 硬い塩基のカルボン酸イオンを用いている ${ }^{3)}$, 4$)$.この自己 組織化膜を化学修飾して一次元あるいは二次元重合体の 皮膜とすることで，ホウ酸塩緩衝溶液中における $\mathrm{Cl}^{-}$に よる不動態皮膜破壊を完全に防止することができる（腐 食科学におけるナノテクノロジー (その 3 $)^{9)}$ 参照). ま た，不動態化した Fe 電極を二次元重合体の皮膜で覆う と, 大気開放 $0.1 \mathrm{M} \mathrm{NaCl}$ 中で不動態皮膜が破壊されない 限り，P>99.9\% と腐食を完全に防止できる ${ }^{9), 10)}$.

* ₹ 158-0083 東京都世田谷区奥沢 2-23-26（2-23-26, Okusawa, Setagayaku, Tokyo, 158-0083 Japan) 


\section{2. 炭素一金属共有結合により生成した自己組織化膜}

炭素電極たとえばグラファイトやグラッシーカーボン 上に有機化合物を固定化し，電極表面に種々の特性を持 たせることは，修飾電極として広く使われている。この 電極上の固定化は電極，有機化合物共に炭素で構成され ているので，C-C 結合によって行われるのが一般的であ る. その固定法の一つに, ベンゼンジアゾニウムイオン $\mathrm{C}_{6} \mathrm{H}_{5} \mathrm{~N}_{2}{ }^{+}$をカソード還元によって電極 $[\mathrm{C}]$ 上に電気化学的 にC-C 結合を作る方法がある11)-14)。

$$
[\mathrm{C}]+\mathrm{C}_{6} \mathrm{H}_{5} \mathrm{~N}_{2}{ }^{+}+\mathrm{e}^{-} \rightarrow[\mathrm{C}]-\mathrm{C}_{6} \mathrm{H}_{5}+\mathrm{N}_{2}
$$

生成した $\mathrm{C}-\mathrm{C}$ 結合は安定な共有結合であるため，吸着は 非常に強い.

最近，この反応を応用して，金属電極上に $\mathrm{M}-\mathrm{C}$ 結合 によって有機化合物を固定化することが試みられてい る15)-19) $・ p$-置換ベンゼンジアゾニウムイオン $\mathrm{XC}_{6} \mathrm{H}_{4} \mathrm{~N}_{2}{ }^{+}$ (X: $\mathrm{CH}_{3}, \mathrm{COOH}, \mathrm{NO}_{2}$ など) と金属 $(\mathrm{Cu}, \mathrm{Fe}, \mathrm{Co}, \mathrm{Ni}, \mathrm{Zn}$, $\mathrm{Pt}, \mathrm{Au}$ など）を用い，電解還元あるいは単に溶液に浸漬 することによって，表面に $\mathrm{M}-\mathrm{C}$ 結合を作り吸着させ $ろ^{15)-22)}$.

$$
[\mathrm{M}]+\mathrm{XC}_{6} \mathrm{H}_{4} \mathrm{~N}_{2}{ }^{+}+\mathrm{e}^{-} \rightarrow[\mathrm{M}]-\mathrm{C}_{6} \mathrm{H}_{4} \mathrm{X}+\mathrm{N}_{2}
$$

生成した $\mathrm{M}-\mathrm{C}$ 結合は $\mathrm{X}$ 線光電子分光法 (XPS) の C $1 \mathrm{~s}$ スペクトルによって確認されている16),19)-21)。この反応は 中間体に遊離基（フリーラジカル）を生成するために， 重合反応を起こしやすく, 単分子皮膜ではなく重合皮膜 が表面に生成することがある。

$$
\begin{aligned}
& {[\mathrm{M}]+n \mathrm{XC}_{6} \mathrm{H}_{4} \mathrm{~N}_{2}{ }^{+}+n \mathrm{e}^{-} } \\
& \rightarrow[\mathrm{M}]-\left(\mathrm{C}_{6} \mathrm{H}_{3} \mathrm{X}\right)_{n} \mathrm{H}+n \mathrm{~N}_{2}+n / 2 \mathrm{H}_{2}
\end{aligned}
$$

すでに， $\mathrm{Fe}-\mathrm{C}$ 結合によって $\mathrm{Fe}$ 表面上に吸着した皮膜 について，酸性あるいは中性水溶液中における腐食防止 効果が検討された16)，17），22． しかし，これらの皮膜が単 分子皮膜か重合皮膜であるか識別されていないので，規 則正しい構造を持った皮膜であることは疑わしい. そこ でまず共有結合によって吸着した単分子皮膜（自己組織 化膜）を $\mathrm{Fe}$ 上に作製し，大気開放 $0.5 \mathrm{M} \mathrm{NaCl}$ 中におけ る分極測定から腐食防止能力を評価し, 接触角測定, XPS，FTIR 反射分光法などによって皮膜の構造を解明す ることにした。

\section{Fe 表面上のトルエンおよびヒドロキシ メチルベンゼン自己組織化膜 ${ }^{23), 24}$}

$\mathrm{Fe}$ 表面に共有結合で吸着した自己組織化膜の作製の試 みをp-トルエンジアゾニウムイオン $\mathrm{CH}_{3} \mathrm{C}_{6} \mathrm{H}_{4} \mathrm{~N}_{2}{ }^{+}$を用い て行った。一般のジアゾニウムイオンの反応は冷却した 水溶液中で行われるが, 文献16)にある電解還元はアセ卜 ニトリル $\mathrm{CH}_{3} \mathrm{CN}(\mathrm{AN})$ 中で行っているので, ジアゾニウ ム塩を単離しなければならない. そこで, テトラフルオ ロホウ酸トルエンジアゾニウム $\mathrm{CH}_{3} \mathrm{C}_{6} \mathrm{H}_{4} \mathrm{~N}_{2} \mathrm{BF}_{4}$ (TDFB) を合成, 単離した ${ }^{23)}$. 最初は文献16)に従って Fe 電極を 用い, $2 \times 10^{-3} \mathrm{M}$ TDFB と $0.1 \mathrm{M}$ テトラフルオロホウ酸 テトラブチルアンモニウム $\left(\mathrm{C}_{4} \mathrm{H}_{9}\right){ }_{4} \mathrm{NBF}_{4}$ （TBAFB，支持 電解質) の $\mathrm{AN}$ 溶液 $\left(25^{\circ} \mathrm{C}\right)$ 中, $-1.013 \mathrm{~V}$ vs. $\mathrm{Ag} / \mathrm{Ag}^{+}$ (AN 溶液)（この電位は同じ溶液中での $\mathrm{Fe}$ 電極を用いた サイクリックボルタモグラムのピーク電位よりも $0.30 \mathrm{~V}$
負の電位である）で 0.5 50 min 定電位カソード還元を した23).

$$
\begin{aligned}
{[\mathrm{Fe}]+\mathrm{CH}_{3} \mathrm{C}_{6} \mathrm{H}_{4} \mathrm{~N}_{2} \mathrm{BF}_{4}+\mathrm{e}^{-} } & \\
& \rightarrow[\mathrm{Fe}]-\mathrm{C}_{6} \mathrm{H}_{4} \mathrm{CH}_{3}+\mathrm{N}_{2}+\mathrm{BF}_{4}-
\end{aligned}
$$

皮膜の評価は大気開放 $0.5 \mathrm{M} \mathrm{NaCl}\left(30^{\circ} \mathrm{C}\right)$ 中に $1.5 \mathrm{~h}$ あ るいは長時間浸漬した後の分極測定およびXPSなどの表 面分析により行った。分極曲線から腐食電流密度を求め, (4) 式から $P$ を求めた。処理時間 $t_{\mathrm{m}}=5 \mathrm{~min}$ 以上の電解還 元では $P=78 \%$ が得られたが，XPSの結果から重合体の 皮膜であることが分かった. $t_{\mathrm{m}}=1 \mathrm{~min}$ のときに自己組 織化膜と思われる皮膜が生成し（分極曲線を図 2 に示 す)，そのときの $P$ は $31.8 \%$ でった ${ }^{23)}$.

自己組織化膜を化学修飾するには, 末端に反応基を導 入する必要がある. 従来から用いた方法で化学修飾する ために, 末端に水酸基が入ったテトラフルオロホウ酸 p-ヒドロキシメチルベンゼンジアゾニウム $\mathrm{HOCH}_{2} \mathrm{C}_{6} \mathrm{H}_{4} \mathrm{~N}_{2} \mathrm{BF}_{4}$ （HOMBDFB）を合成し， Fe 表面上に自己組織化膜を作 製した ${ }^{24)}$.

$$
\begin{aligned}
{[\mathrm{Fe}]+\mathrm{HOCH}_{2} \mathrm{C}_{6} \mathrm{H}_{4} \mathrm{~N}_{2} \mathrm{BF}_{4}+\mathrm{e}^{-} } & \\
& \rightarrow[\mathrm{Fe}]-\mathrm{C}_{6} \mathrm{H}_{4} \mathrm{CH}_{2} \mathrm{OH}+\mathrm{N}_{2}+\mathrm{BF}_{4}^{-}
\end{aligned}
$$

定電位電解する電位を決定するために, $5 \times 10^{-4} \mathrm{M}$ の $\mathrm{HOMBDFB}$ と $0.1 \mathrm{M}$ TBAFB を含む $\mathrm{AN}$ 溶液中 $10^{\circ} \mathrm{C}$ 以下 でサイクリックボルタモグラムを測定した。図 1 に示す ように，第 1 サイクルの還元波のピーク電位はー0.751 V vs. $\mathrm{Ag} / \mathrm{Ag}^{+}(\mathrm{AN}$ 溶液 $)$ であったので，この電位において 電解することにした。新しく作製した $5 \times 10^{-4} \mathrm{M}$ $\mathrm{HOMBDFB}$ と $0.1 \mathrm{M}$ TBAFB を含む脱気 $\mathrm{AN}$ 溶液中, $10^{\circ} \mathrm{C}$ 以下で $\mathrm{Pt}$ 対極, $\mathrm{Ag} / \mathrm{Ag}^{+}$( $\mathrm{AN}$ 溶液) 照合電極を用 い, $-0.751 \mathrm{~V}$ において種々の処理時間, 定電位電解して $\mathrm{Fe}$ 電極上にヒドロキシメチルベンゼン $\mathrm{HOCH}_{2} \mathrm{C}_{6} \mathrm{H}_{4}$ (HOMB) 自己組織化膜を作製した。なお，Fe 電極表面

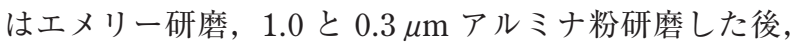
エタノール洗浄, $0.1 \mathrm{M}$ 酢酸の脱気 $\mathrm{AN}$ 溶液中でエッチ ング, 脱気 AN 中で超音波洗浄し, 脱気 AN で洗浄して 直ちに用いた。できるだけ空気に触れないように注意し た. 電解終了後, Fe 電極を大量の AN で繰り返し洗浄し, 真空乾燥して HOMB 自己組織化膜を Fe 上に作製した。

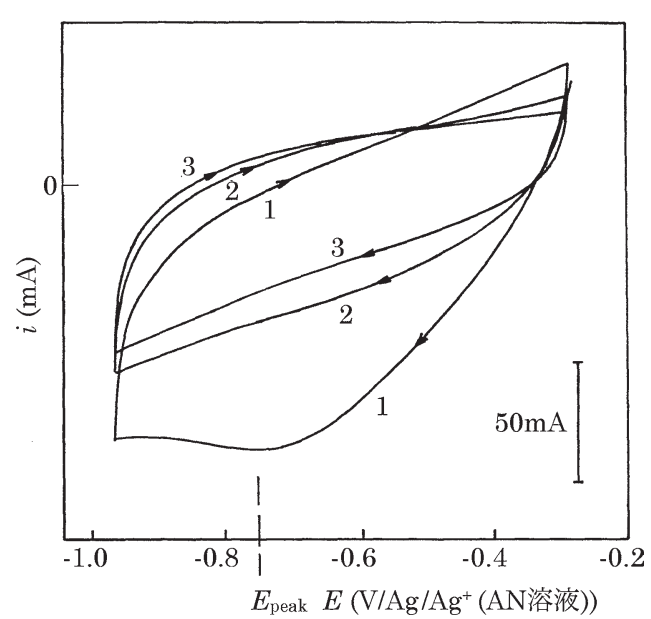

図 $15 \times 10^{-4} \mathrm{M}$ HOMBDFB と $0.1 \mathrm{M}$ TBAFB の AN 溶液 $\left(10^{\circ} \mathrm{C}\right.$ 以下）中に扔ける $\mathrm{Fe}$ 電極のサイクリックボルタモグラム (走查速度 : $0.2 \mathrm{~V} / \mathrm{s})^{24)}\left(E_{\text {peak }}=-0.751 \mathrm{~V}\right.$ vs. $\mathrm{Ag} / \mathrm{Ag}^{+}(\mathrm{AN}$ 溶液) 
大気開放 $0.5 \mathrm{M} \mathrm{NaCl}$ 中（浸漬時間 $t=1.5 \mathrm{~h}$ ）において この皮膜で覆った $\mathrm{Fe}$ 電極の分極測定を行った。裸とト ルエン自己組織化膜およびこの皮膜で覆ったときの分極 曲線を図 2 に示す。アノード反応，カソード反応共に抑 制されたが，アノード反応の抑制の方が著しい。共有結 合による吸着によって表面の $\mathrm{Fe}$ 原子が安定化したもの と思われる. 分極曲線から腐食電流密度を求め, $P$ を得 た. 図 3 に HOMB 自己組織化膜の $P$ と処理時間 $t_{\mathrm{m}}$ の関 係を示す. $t_{\mathrm{m}}$ の増加と共に $P$ は増加し, $t_{\mathrm{m}}=60 \mathrm{~min}$ 付近 で丘を作った後，再び増加した。皮膜の性質を調べる目 的で，水滴を用いた接触角 $\theta$ を求め，図 3 に $\theta$ と $t_{\mathrm{m}}$ の関 係を併せて示す. $\mathrm{Fe}$ 表面の $\theta$ （図 $3, t_{\mathrm{m}}=0 \mathrm{~min}$ ）は $57^{\circ}$ であったが, $t_{\mathrm{m}}$ の増加と共に $\theta$ は減少し, $t_{\mathrm{m}}=60 \mathrm{~min}$ において最小值 $\left(\theta=33^{\circ}\right)$ を経て, 再び増加した。この 変化は次のように解釈できる. Fe 表面に HOMB の吸着 が進むにつれて, 皮膜の最外面に $\mathrm{OH}$ 基が配列するため に親水性となり， $\theta$ は低下する。 $\theta$ の最小值は $\mathrm{OH}$ 基が 最も密に配列したときで, 自己組織化膜に対応する. 最 小值 $\left(\theta=33^{\circ}\right)$ は $\mathrm{OH}$ 基を末端に持つ化合物の自己組織 化膜の $\theta$ に近い25). こうして $t_{\mathrm{m}}=60 \mathrm{~min}$ において最も密 に配列した HOMB の自己組織化膜が生成するものと判 断した. $t_{\mathrm{m}}$ の増加と共に $\theta$ が再び増加するのは, 高分子

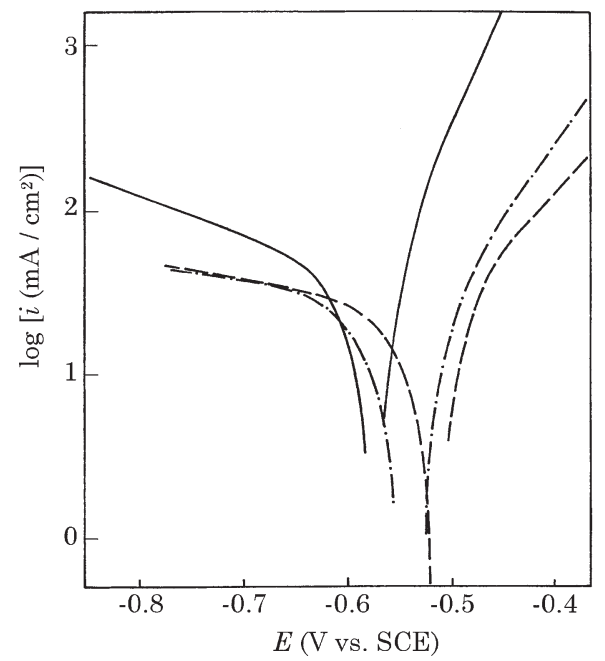

図 2 大気開放 $0.5 \mathrm{M} \mathrm{NaCl}$ 中における裸 (一) とトルエン $(--)$ および HOMB 自己組織化膜 $(-\cdot-)$ で覆った Fe 電 極の分極曲線（電位 $E$, 電流密度 $i)^{24)}$

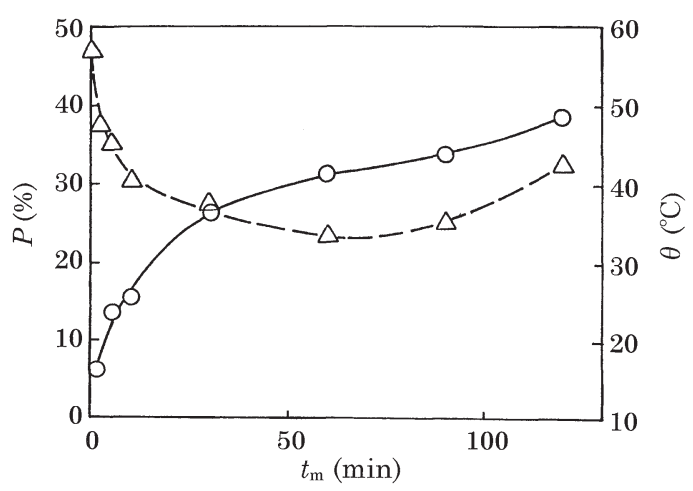

図 $3 \mathrm{HOMBDFB}$ の AN 溶液中における化学修飾時間 $t_{\mathrm{m}}$ による 腐食防止率 $P(\bigcirc)$ および接触角 $\theta(\triangle)$ の変化 ${ }^{24)}$
皮膜の生成によって配列が乱れるために, 疎水性が増加 すると考えればよい. したがって, 図 3 の $P$ と $t_{\mathrm{m}}$ の関係 においても， $t_{\mathrm{m}}$ の増加と共に $t_{\mathrm{m}}=60 \mathrm{~min}$ までは自己組織 化膜が成長し， $t_{\mathrm{m}}=90 \mathrm{~min}$ 以上では高分子皮膜となるこ とで $P$ が増加したものである.

$t_{\mathrm{m}}=60 \mathrm{~min}$ における $P$ は $31.0 \%$ で，トルエン自己組織 化膜の $P=31.8 \%$ に近く, 自己組織化膜の $P$ としては低 い值であった。これは HOMB やトルエン分子が小さい こと, ベンゼン環が環と平行な方向に長く, ち密な皮膜 を作りにくいことなどが原因として考えられる.

図 4 は $t_{\mathrm{m}}=60 \mathrm{~min}$ 処理した皮膜で覆った $\mathrm{Fe}$ 表面の FTIR 反射スペクトルである. $3652 \mathrm{~cm}^{-1}$ に $\mathrm{OH}$ 伸縮振動, 1576 と $1066 \mathrm{~cm}^{-1}$ にベンゼン環の C-C 伸縮振動と C-H 変角振動が現れている。 $2274 \mathrm{~cm}^{-1}$ にあったジアゾニウ ムイオンの $\mathrm{N} \equiv \mathrm{N}^{+}$伸縮振動のバンドが消滅し, $\mathrm{N}_{2}{ }^{+}$が除 去された。

図 5 は同様に作製した皮膜で覆った $\mathrm{Fe}$ 表面の $\mathrm{X}$ 線光 電子スペクトルである. $\mathrm{Ar}^{+}$スパッ夕をしているので, スパッ夕時間 $t_{\mathrm{s}}=0 \mathrm{~s}$ が最表面, $t_{\mathrm{s}}$ の増加と共に内部のス

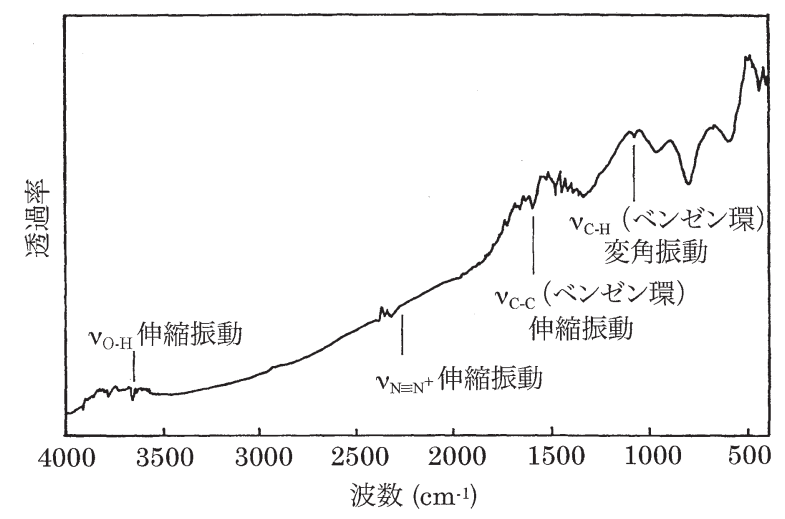

図 4 HOMB 自己組織化膜で覆った Fe 表面の FTIR 反射スペク トル24)

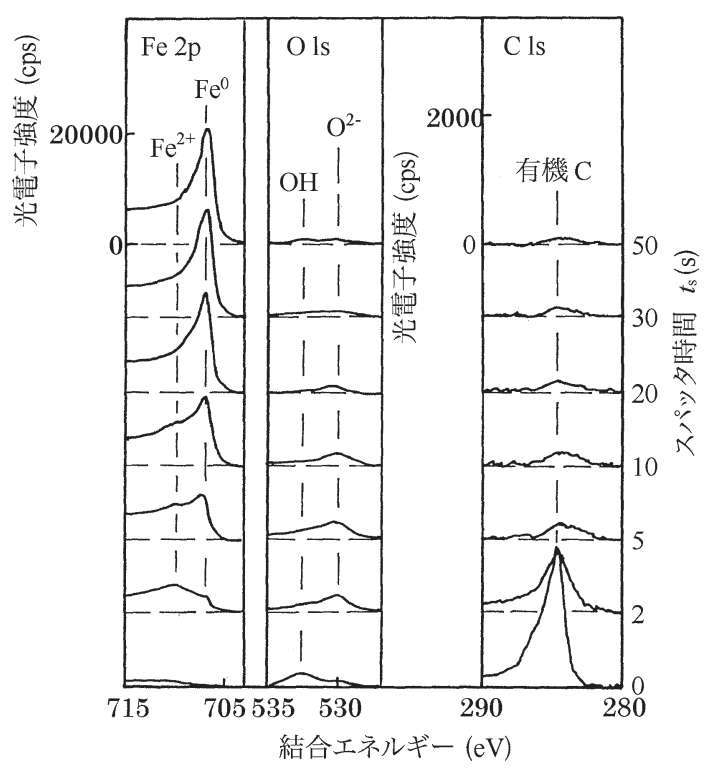

図 5 HOMB 自己組織化膜で覆った $\mathrm{Fe}$ 表面の $\mathrm{X}$ 線光電子スペ クトル $\left(\mathrm{Fe} 2 \mathrm{p}, \mathrm{O} 1 \mathrm{~s}\right.$ 抢よび C 1s) ${ }^{24)}$ (深さ方向の組成変化 をスパッ夕時間 $t_{\mathrm{s}}$ で示す) 
表 $1 \mathrm{Fe}$ 上に作製した皮膜の XPSのC 1s スペクトルにおける 裸の $\mathrm{Fe}$ スペクトルで補正したピーク強度 $N$ (スパッ夕時 間 $\left.t_{\mathrm{s}}=0 \mathrm{~s}\right)^{24)}$

\begin{tabular}{|c|c|}
\hline 皮 膜 & $N(\mathrm{cps})$ \\
\hline トルエン自己組織化膜 & 1031 \\
\hline HOMB 自己組織化膜 & 1165 \\
\hline トルエンチオール自己組織化膜 & 1247 \\
\hline トルエン高分子皮膜 & 7530 \\
\hline C8TES で化学修飾した HOMB 自己組織化膜 & 1991 \\
\hline BTESE+C8TES で化学修飾した HOMB 自己組織化膜 & 2577 \\
\hline $\begin{array}{l}\text { BTESE + C8TES で化学修飾した後 C8TES で追加修飾 } \\
\text { した HOMB 自己組織化膜 }\end{array}$ & 3083 \\
\hline $\begin{array}{l}\text { TES }+\mathrm{C}_{8} \mathrm{DO}+\mathrm{C}_{8} \mathrm{TES} \text { で化学修飾した HOMB 自己組織 } \\
\text { 化膜 }\end{array}$ & 3214 \\
\hline $\begin{array}{l}2\left(\mathrm{TES}+\mathrm{C}_{8} \mathrm{DO}\right)+\mathrm{BTESE}+\mathrm{C}_{8} \mathrm{TES} \text { で化学修飾した } \\
\text { HOMB 自己組織化膜 }\end{array}$ & 3704 \\
\hline
\end{tabular}

ペクトルを示している. Fe $2 \mathrm{p}_{3 / 2}$ と O $1 \mathrm{~s}$ スペクトルに $\mathrm{Fe}^{2+}$ と $\mathrm{O}^{2-}$ のピークが現れ, 少量の酸化鉄の存在を示し た。技そらく, 皮膜処理あるいはXPS 測定中に混入した $\mathrm{H}_{2} \mathrm{O}$ または $\mathrm{O}_{2}$ によって生成したものと思われるが，皮 膜にややち密さが欠けていることを暗示している．Ｏ 1s スペクトルには最表面に $\mathrm{OH}$ 基の存在を示すピークが現 れた。

C 1s スペクトルに有機炭素のピークが現れたが，この ピークには不純物の炭素のピークが含まれている。そこ で，裸の $\mathrm{Fe}$ 表面を同じように調製し，C $1 \mathrm{~s}$ スペクトル を測定した。 HOMB 自己組織化膜で覆った $\mathrm{Fe}$ 表面の $\mathrm{C}$ 1s ピーク強度から裸の $\mathrm{Fe}$ 表面の $\mathrm{C}$ 1s ピーク強度を差し 引いて、混入不純物炭素分を補正した. 表 1 はトルエン 自己組織化膜, HOMB 自己組織化膜, トルエン高分子皮 膜および比較のためのトルエンチオール $\mathrm{CH}_{3} \mathrm{C}_{6} \mathrm{H}_{4} \mathrm{SH}$ （TT）自己組織化膜の補正したピーク強度 $N$ を示す. TT 自己組織化膜は従来からの方法7) によって Fe 表面に作 製した。 HOMB 自己組織化膜の $N$ はトルエン自己組織 化膜や TT 自己組織化膜の $N$ とほほ等しく, C 量の等し い，同じょうな吸着皮膜であることを示した。高分子皮 膜の $N$ は極端に大きかった。

HOMB 自己組織化膜の耐久性を知るために，24h ま で $0.5 \mathrm{M} \mathrm{NaCl}$ 中に浸漬した後の分極測定から得た $P$ を 浸漬時間 $t$ に対してプロットしたものが図 6 である。典 型的な配位結合によって化学吸着する TT の $P$ と比較し た。 $t=1.5 \mathrm{~h}$ における $P$ は, HOMB 自己組織化膜が $31.0 \%$ ，TT 自己組織化膜が $28.0 \%$ とあまり変わらないの に, $t=24 \mathrm{~h}$ においては，前者がほとんど低下しないのに 対して後者の $P$ は 1 桁まで低下した。一般に，溶液中に 無添加のときの吸着型抑制剤の抑制効果が急速に低下す ることはよく見られる現象で，特にこの場合は，表面が 酸化されて硬い酸の $\mathrm{Fe}^{3+}$ が生成し, 軟らかい塩基の $\mathrm{TT}$ が再吸着できないので，Pの低下は当然である。皇れに 対して, HOMB 自己組織化膜の $P$ が低下しないのは, 腐食環境に対する耐久性があることで, 非常に優れた吸 着保護皮膜の特徵と言える。これは $\mathrm{Fe}-\mathrm{C}$ 間の共有結合 による吸着が強いためと考えられる。

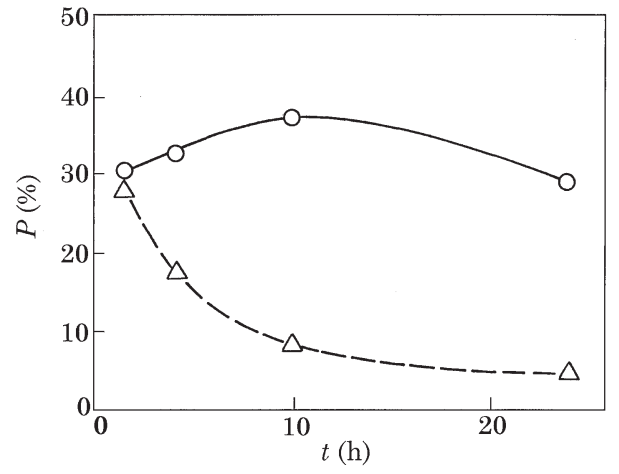

図 6 大気開放 $0.5 \mathrm{M} \mathrm{NaCl}$ 中における $\mathrm{HOMB}(\bigcirc)$ および $\mathrm{TT}$ 自 己組織化膜 $(\triangle)$ の $P$ と $0.5 \mathrm{M} \mathrm{NaCl}$ 中の浸漬時間 $t$ の関 係 ${ }^{24)}$

強い吸着結合の生成は次のように考えている。ベンゼ ン環の $\mathrm{C}$ 原子の $s p^{2}$ 混成軌道と $\mathrm{Fe}$ 原子の $d$ 軌道（たと えば $d_{z}{ }^{2}$ 軌道）が重なり合い各々から 1 個ずつの電子が 入って $\sigma$-共有結合を作る.

$[\mathrm{Fe}] \cdot+\cdot \mathrm{C}_{6} \mathrm{H}_{4} \mathrm{CH}_{2} \mathrm{OH} \rightarrow[\mathrm{Fe}]: \mathrm{C}_{6} \mathrm{H}_{4} \mathrm{CH}_{2} \mathrm{OH}$

さらに, $\mathrm{Fe}$ 原子の対電子が入った $d$ 軌道（たとえば $d_{\mathrm{x} z}$ または $d_{\mathrm{yz}}$ 軌道) と $\mathrm{C}$ 原子の空の $\pi$ *軌道（反結合性軌道） が重なって逆供与 $\pi$-結合を作る。

$[\mathrm{Fe}]:+\mathrm{C}_{6} \mathrm{H}_{4} \mathrm{CH}_{2} \mathrm{OH} \rightarrow[\mathrm{Fe}]: \mathrm{C}_{6} \mathrm{H}_{4} \mathrm{CH}_{2} \mathrm{OH}$

ベンゼン環の非局在化した $\pi$ 電子による共鳴構造とこの 結合の $\pi$ 電子が, 次式のように, 一体化して共鳴構造を 作り，より安定な結合となる可能性がある.

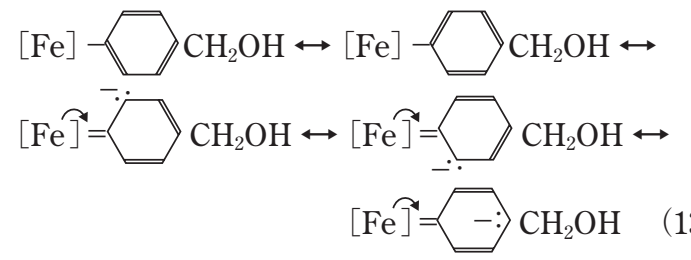

(๙は逆供与の電子の移動を示す.)

これらの $\sigma$-共有結合と逆供与 $\pi$-結合の重複によって強 い吸着結合が生成する ${ }^{27)}$.

一方, 配位結合によって吸着した TTの S 原子には $\pi^{*}$ 軌道が存在しないので, Fe からの逆供与による できず， $\mathrm{Fe}-\mathrm{S}$ 結合は $\mathrm{Fe}-\mathrm{C}$ 結合よりも弱くなる． $\mathrm{Fe}-\mathrm{C}$ 結合の生成が表面の $\mathrm{Fe}$ 原子を安定化させ， $\mathrm{NaCl}$ 中にお ける長時間の浸漬に対して耐久性を示したものと思われ る $^{26,27)}$.

\section{HOMB 自己組織化膜の化学修飾による 一次元重合体保護皮膜の作製28)}

HOMB 自己組織化膜の腐食防止効果を向上させるため に，この解説シリーズ (つづき) ${ }^{8)}$ ，(その 3) ${ }^{9)}$ と同じ方 法でアルキルトリエトキシシラン $\mathrm{C}_{n} \mathrm{H}_{2 n+1} \mathrm{Si}\left(\mathrm{OC}_{2} \mathrm{H}_{5}\right)_{3}$ $\left(\mathrm{C}_{n} \mathrm{TES}, n=8\right.$ または 18) を用いて化学修飾し, 一次元重 合体の皮膜を作製した。

$$
\begin{aligned}
& x[\mathrm{Fe}]-\mathrm{C}_{6} \mathrm{H}_{4} \mathrm{CH}_{2} \mathrm{OH}+x \mathrm{C}_{n} \mathrm{H}_{2 n+1} \mathrm{Si}\left(\mathrm{OC}_{2} \mathrm{H}_{5}\right)_{3}+x \mathrm{H}_{2} \mathrm{O} \\
& \mathrm{O} \\
& \rightarrow\left\{[\mathrm{Fe}]-\mathrm{C}_{6} \mathrm{H}_{4} \mathrm{CH}_{2} \mathrm{OSiC}_{1}^{\prime} \mathrm{H}_{2 n+1}\right\}_{x}+3 x \mathrm{C}_{2} \mathrm{H}_{5} \mathrm{OH}
\end{aligned}
$$




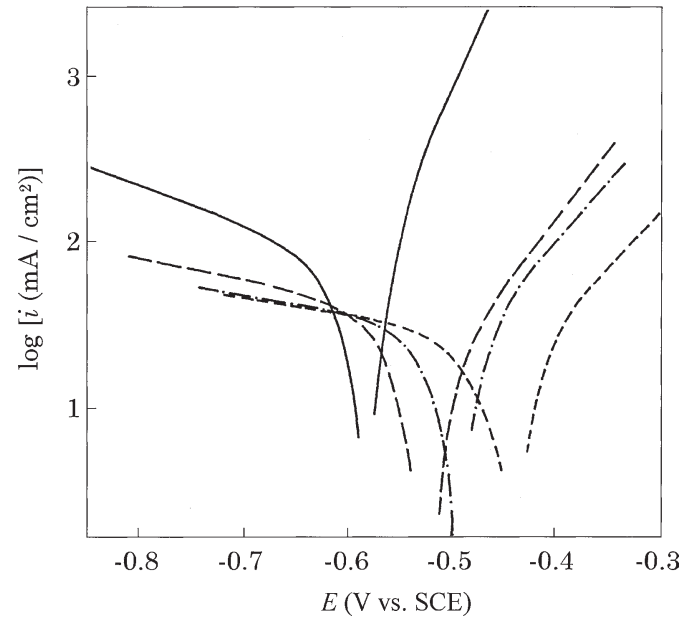

図 7 大気開放 $0.5 \mathrm{M} \mathrm{NaCl}$ 中における裸 (一) と $\mathrm{C}_{8} \mathrm{TES}(--)$, BTESE $+\mathrm{C}_{8}$ TES $(-\cdot-)$ および BTESE $+\mathrm{C}_{18}$ TES で化学修飾 した HOMB 自己組織化膜 (---) で覆った $\mathrm{Fe}$ 電極の分極 曲線28), 29)

$\mathrm{HOMB}$ 自己組織化膜で覆った $\mathrm{Fe}$ 電極を $5 \times 10^{-2} \mathrm{M}$ $\mathrm{C}_{8}$ TES または $5 \times 10^{-4} \mathrm{M} \mathrm{C}_{18}$ TES のアセトン溶液中 $40^{\circ} \mathrm{C}$ で $1 \mathrm{~h}$ あるいは $118 \mathrm{~h}$ 処理した後, $1 \times 10^{-2} \mathrm{M} \mathrm{H}_{2} \mathrm{O}$ アセ トン溶液中 $40^{\circ} \mathrm{C}$ で $10 \mathrm{~min}$ 加水分解, $\mathrm{AN}$ で洗浄し, 真空 乾燥して一次元重合体の皮膜を作製した28).

なお，表面は二次元の世界であるので，吸着分子は二 次元に広がって表面を覆っている. その吸着分子が一次 元につながっているものが一次元重合体皮膜で, 一次元 重合体が 1 個吸着しているのではない.

これらの皮膜で覆った $\mathrm{Fe}$ 電極を大気開放 $0.5 \mathrm{M} \mathrm{NaCl}$ 中に $30^{\circ} \mathrm{C}$ で浸漬し， $1.5 \mathrm{~h}$ 後に分極測定を行った。図 7 に $\mathrm{C}_{8} \mathrm{TES}$ で化学修飾した一次元重合膜で覆った Fe 電極 の $0.5 \mathrm{M} \mathrm{NaCl}$ 中の分極曲線を示す. アノード, カソード 両反応を抑制したが, 前者の方が著しい. 強い吸着と架 橋構造によって, 表面の $\mathrm{Fe}$ 原子が安定化し, アノード 反応が抑制されたものである. 分極曲線から得た $P$ は $\mathrm{C}_{8} \mathrm{TES}$ を用いたときが $53.6 \% ， \mathrm{C}_{18} \mathrm{TES}$ を用いたときが $62.5 \%$ で，HOMB 自己組織化膜の $P=31.0 \%$ よりずっ と向上したが，まだ十分ではなかった。しかし，皮膜の 耐久性は高く, $\mathrm{C}_{8}$ TES を用いた皮膜の $P$ は $24 \mathrm{~h}$ の浸漬 後においても $48 \%$ であった28).

図 8 はこの皮膜で覆った $\mathrm{Fe}$ 電極を $0.5 \mathrm{M} \mathrm{NaCl}$ 中に $4 \mathrm{~h}$ 浸漬し，一部（右側の部分）に全面腐食が発生した 表面の電子顕微鏡写真と $\mathrm{AB}$ 間の線分析を示す。腐食し た部分に $\mathrm{Cl}^{-}$が集中し，腐食生成物が表面を覆っていた が，その部分にも C が存在していた。すなわち，腐食し た部分に皮膜が存在し，腐食防止効果をあげていた28).

$\mathrm{C}_{8}$ TES を用いて化学修飾し作製した一次元重合膜の $\theta$ は $77 \pm 2^{\circ}$ で，アルカンチオールの自己組織化膜のような 高い $\theta$ は得られなかった.これはかさ高いベンゼン環が 直接 $\mathrm{Fe}$ 表面に結合しているためにち密な構造をとりえ ず，すき間に酸化物を生成するために疎水性が増加しな かったものである. FTIR 反射スペクトルから重合反応 が十分に行われていること, また X 線光電子スぺクトル から少量の酸化鉄が皮膜内に存在することおよび $\mathrm{O}$ と $\mathrm{Si}$ を含む有機皮膜で覆われていることが明らかになった。

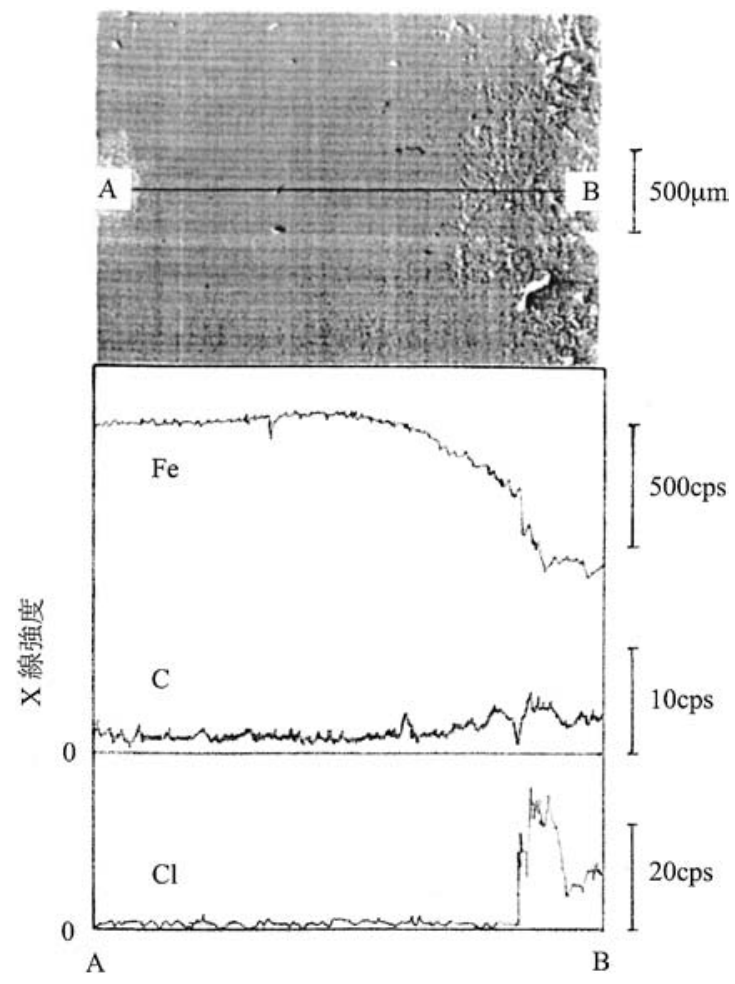

図 $8 \mathrm{C}_{8}$ TES で化学修飾した HOMB 自己組織化膜で覆った $\mathrm{Fe}$ 電極を $0.5 \mathrm{M} \mathrm{NaCl}$ 中に $4 \mathrm{~h}$ 浸漬した後の表面の電子顕微 鏡写真と $\mathrm{AB}$ 間の $\mathrm{Fe}, \mathrm{C}$ および $\mathrm{Cl}$ の線分析 ${ }^{28)}$

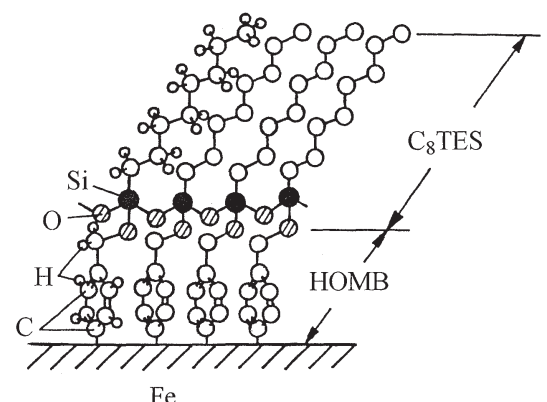

図 $9 \mathrm{C}_{8}$ TES で化学修飾した HOMB 自己組織化膜（一次元重合 体皮膜）の模式図 ${ }^{28}$

$\mathrm{C}_{8}$ TES で化学修飾した皮膜について C 1s スペクトルの 補正したピーク強度 $N$ は，表 1 のように，化学修飾によ って皮膜の C 含有量が増加した。

図 9 に $\mathrm{C}_{8}$ TES で化学修飾した HOMB 自己組織化膜の 模式図を示す. $\mathrm{Fe}-\mathrm{C}$ 結合により $\mathrm{Fe}$ 表面に吸着し, HOMB と $\mathrm{C}_{8} \mathrm{TES}$ が $\mathrm{O}-\mathrm{Si}$ 結合で結ばれている。伸長したアルキ ル基は表面の垂直に対して約 $35^{\circ}$ 傾いていて，吸着分子 間を縮めている。隣接吸着分子との間に $\mathrm{Si}-\mathrm{O}-\mathrm{Si}$ 結合に よって架橋し, 一次元重合体となっている. 環と平行方 向のベンゼン環の長さは約 $0.67 \mathrm{~nm}$ であるのに対して $\mathrm{Si}-\mathrm{O}-\mathrm{Si}$ 結合距離は $0.29 \mathrm{~nm}$ であるため, ベンゼン環と 平行方向の重合はできない。また, 皮膜の厚さ $d$ は約 $1.8 \mathrm{~nm}$ と薄く, 高い $P$ が得られない原因となっている.

$\mathrm{C}_{18}$ TES を用いて化学修飾した HOMB 自己組織化膜の 一次元重合体皮膜の $\theta$ は $t_{\mathrm{m}} \geq 54 \mathrm{~h}$ において平均 $78^{\circ}$ とあ まり高くなく，ち密な皮膜でないことを示した。アルキ 
ル基が長くなったために皮膜の厚さは増加し， $d=3.0 \mathrm{~nm}$ であった。このため， $\mathrm{C}_{8} \mathrm{TES}$ を用いたときよりも $P$ は増 加した ${ }^{28)}$.

\section{HOMB 自己組織化膜の化学修飾による 二次元重合体保護皮膜の作製29)}

HOMB 自己組織化膜を化学修飾して二次元重合体の皮 膜を作製するために，1，2-ビス（トリエトキシシリル） エタン $\left(\mathrm{C}_{2} \mathrm{H}_{5} \mathrm{O}\right)_{3} \mathrm{Si}\left(\mathrm{CH}_{2}\right)_{2} \mathrm{Si}\left(\mathrm{OC}_{2} \mathrm{H}_{5}\right)_{3}$ (BTESE) と $\mathrm{C}_{n} \mathrm{TES}$ を用い化学修飾した。まず，HOMB 自己組織化膜を BTESE と反応させ，次に水で処理した。

$$
\begin{array}{r}
x[\mathrm{Fe}]-\mathrm{C}_{6} \mathrm{H}_{4} \mathrm{CH}_{2} \mathrm{OH}+x\left(\mathrm{C}_{2} \mathrm{H}_{5} \mathrm{O}\right)_{3} \mathrm{Si}\left(\mathrm{CH}_{2}\right)_{2} \mathrm{Si}\left(\mathrm{OC}_{2} \mathrm{H}_{5}\right)_{3} \\
+4 x \mathrm{H}_{2} \mathrm{O}
\end{array}
$$

$\stackrel{1}{\mathrm{O}}$

$\rightarrow\left\{[\mathrm{Fe}]-\mathrm{C}_{6} \mathrm{H}_{4} \mathrm{CH}_{2} \mathrm{OSi}\left(\mathrm{CH}_{2}\right)_{2} \mathrm{Si}(\mathrm{OH})_{3}\right\}_{x}+6 x \mathrm{C}_{2} \mathrm{H}_{5} \mathrm{OH}$

さらに $\mathrm{C}_{n} \mathrm{TES}$ で化学修飾して,

$$
\begin{aligned}
& y\left\{[\mathrm{Fe}]-\mathrm{C}_{6} \mathrm{H}_{4} \mathrm{CH}_{2} \mathrm{OS} \stackrel{1}{!}_{1}\left(\mathrm{CH}_{2}\right)_{2} \mathrm{Si}(\mathrm{OH})_{3}\right\}_{x}+ \\
& x y \mathrm{C}_{n} \mathrm{H}_{2 n+1} \mathrm{OSi}\left(\mathrm{OC}_{2} \mathrm{H}_{5}\right)_{3} \\
& \mathrm{O}_{1}^{1} \mathrm{O}^{\mathrm{O}}
\end{aligned}
$$

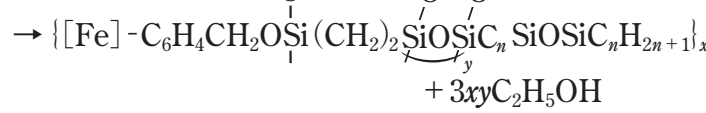

のように，二次元重合体の皮膜を作製した。この皮膜を $\left\lceil\mathrm{BTESE}+\mathrm{C}_{n}\right.$ TES で化学修飾した HOMB 自己組織化膜」 と呼ぶことにする。作製方法は $5 \times 10^{-2} \mathrm{M}$ BTESE のアセ トン溶液中, $40^{\circ} \mathrm{C}$ で $2 \mathrm{~h}$ 浸漬した後, $1 \times 10^{-2} \mathrm{M} \mathrm{H}_{2} \mathrm{O}$ ア セトン溶液中で $40^{\circ} \mathrm{C}$ で $1.5 \mathrm{~h}$ 処理し, $\mathrm{AN}$ で洗浄した。 次に, $5 \times 10^{-2} \mathrm{M} \mathrm{C}_{8} \mathrm{TES}$ アセトン溶液中, $40^{\circ} \mathrm{C}$ で $2 \mathrm{~h}$ ま たは $5 \times 10^{-4} \mathrm{M} \mathrm{C}_{18}$ TES のアセトン溶液中 $40^{\circ} \mathrm{C}$ で $91 \mathrm{~h}$ 化 学修飾し, $\mathrm{H}_{2} \mathrm{O}$ アセトン溶液中 $40^{\circ} \mathrm{C}$ で $10 \mathrm{~min}$ 処理した 後, AN で洗浄して二次元重合膜を完成させた.

大気開放 $0.5 \mathrm{M} \mathrm{NaCl}$ 中における皮膜で覆った $\mathrm{Fe}$ 電極 の分極測定を行った。図 7 に分極曲線を併せて示す。力 ソード反応よりもアノード反応の抑制が著しいのは，架 橋構造が増加するために Fe 原子の安定化が大きいこと と, 皮膜が薄く, やや疎であるために酸素の拡散に対す る妨害が十分でないためである。分極曲線から得た $P$ は $t=1.5 \mathrm{~h}$ において $\mathrm{C}_{8} \mathrm{TES}$ を用いたときが $63.9 \%, \mathrm{C}_{18} \mathrm{TES}$ を用いたときが $68.5 \%$ であった． $\mathrm{C}_{18} \mathrm{TES}$ を用いたときの $P$ は $t_{\mathrm{m}}$ の増加によってわずかずつ増加し, $t_{\mathrm{m}}=138 \mathrm{~h}$ の ときのPは $70.2 \%$ あった。

BTESE $+\mathrm{C}_{8}$ TES で化学修飾した HOMB 自己組織化膜 で覆った $\mathrm{Fe}$ 表面の XPSの C 1s スペクトル強度は C 含 有量の増加を示したが， $\theta$ は $68 \sim 75^{\circ}$ と一次元重合膜よ りも低かった。二次元重合膜の FTIR 反射スペクトルは $3500 \mathrm{~cm}^{-1}$ 付近に小さい $\mathrm{SiOH}$ のバンドを示し, 一部の $\mathrm{SiOH}$ が未反応であることを暗示した。 かさ高いベンゼ ン環が表面に直接結合しているために，ち密さにやや欠 けていることとベンゼン環と平行方向に重合できないた めに，二次元重合膜は必ずしも完成していない。そのた

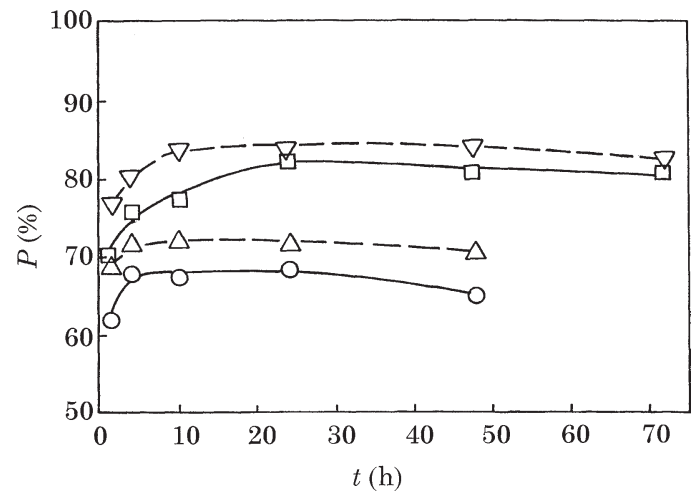

図 $10 \mathrm{BTESE}+\mathrm{C}_{8} \mathrm{TES}(\bigcirc)$ および $\mathrm{BTESE}+\mathrm{C}_{18} \mathrm{TES}(\triangle)$ で化学 修飾した HOMB 自己組織化膜（二次元重合膜）とそれ

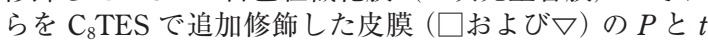
の関係 ${ }^{29)}, 30$

め，Pや $\theta$ がやや低くなっているものと考えた。また， $d$ は BTESE $+\mathrm{C}_{8}$ TES で化学修飾したときが $2.3 \mathrm{~nm}$, $\mathrm{BTESE}+\mathrm{C}_{18} \mathrm{TES}$ のときが $3.6 \mathrm{~nm}$ であった. MUO 自己 組織化膜を化学修飾したときと比べて $d$ が小さく, 酸素 の拡散を十分に防止できないことも $P$ が低い原因になっ ている。

皮膜の耐久性を確かめるために, BTESE $+\mathrm{C}_{8}$ TES およ び BTESE $+\mathrm{C}_{18} \mathrm{TES}\left(t_{\mathrm{m}}=91 \mathrm{~h}\right)$ で化学修飾した HOMB 自 己組織化膜で覆った電極を $0.5 \mathrm{M} \mathrm{NaCl}$ 中に $48 \mathrm{~h}$ 浸漬し, その間の $P$ を測定した。その結果，図 10 に示すように, $P$ は $48 \mathrm{~h}$ の浸漬によってほとんど低下せず，非常に優れ た耐久性を示した。強い共有結合による吸着と架橋構造 の増加によって皮膜が強化されたためである．長時間の 浸漬に対して耐久性があることは，保護皮膜の性質とし て非常に優れた利点である。この利点をさらに生かすに は $P$ をもっと高める必要がある。そのためには,

（1）疎な自己組織化膜を架橋構造によってより密な重 合皮膜にする。

（2）少なくとも $5.5 \mathrm{~nm}$ 位の厚さの皮膜を作製する. ことを目的として, HOMB 自己組織化膜の化学修飾の改 良が試みられた。

\section{6. 繰り返し化学修飾による保護皮膜の改良}

\section{1 よりち密な重合皮膜の作製30}

HOMB 自己組織化膜を BTESE と $\mathrm{C}_{n}$ TES で化学修飾 し作製した二次元重合膜には未反応の $\mathrm{SiOH}$ が存在する. これは吸着分子が隣接分子と離れているために $\mathrm{Si}-\mathrm{O}-\mathrm{Si}$ 結合を作れないためで，この距離を埋めるために， $\mathrm{C}_{8} \mathrm{TES}$ による追加化学修飾を試みた。たとえば,

$$
3 \mathrm{SiOH}+\mathrm{C}_{8} \mathrm{H}_{17} \mathrm{Si}\left(\mathrm{OC}_{2} \mathrm{H}_{5}\right)_{3} \rightarrow(\mathrm{SiO})_{3} \mathrm{SiC}_{8} \mathrm{H}_{17}+3 \mathrm{C}_{2} \mathrm{H}_{5} \mathrm{OH}
$$

のように反応すれば， 3 つの $\mathrm{SiOH}$ を架橋し，離れた分 子間をアルキル基によって埋めることができる.

二次元重合膜で覆った $\mathrm{Fe}$ 電極を $5 \times 10^{-2} \mathrm{M} \mathrm{C}_{8} \mathrm{TES}$ の アセトン溶液中, $40^{\circ} \mathrm{C}$ で $2 \mathrm{~h}$ 反応させ, $1 \times 10^{-2} \mathrm{M} \mathrm{H}_{2} \mathrm{O}$ アセトン溶液中, $40^{\circ} \mathrm{C}$ で $10 \mathrm{~min}$ 処理し, $\mathrm{AN}$ で洗浄して 真空乾燥した。追加修飾した皮膜で覆った表面のXPS か ら皮膜の $\mathrm{C}$ 含有量の増加が認められ， $\theta$ が少し増加した。 
しかし, FTIR 反射スペクトルは依然少量の $\mathrm{SiOH}$ の存在 を示し，1つあるいは 2 つの $\mathrm{SiOH}$ と反応する場合を示 唆した。これらの場合でも分子間を埋める効果があるの で，防止効果への貢献が期待できる.

$0.5 \mathrm{M} \mathrm{NaCl}$ 中における $\mathrm{C}_{8}$ TES で追加化学修飾した BTESE + $\mathrm{C}_{8}$ TES あるいは BTESE + $\mathrm{C}_{18}$ TES で化学修飾し た皮膜の $P$ と $t$ の関係を図 10 に併せて示す. $t=1.5 \mathrm{~h}$ に おける $P$ はそれぞれ $70.3 \%$ と $76.5 \%$ で， $\mathrm{C}_{8}$ TES による追 加化学修飾が皮膜中の空間を埋め, 疎な HOMB 自己組 織化膜の欠点を補ったものと考えられる。また，追加修 飾は皮膜の耐久性にも有効で, $t=72 \mathrm{~h}$ 後の $P$ はそれぞ れ $81.6 \% ， 82.6 \%$ とさらに高くなり, 架橋構造とアルキ ル基の増加が耐久性を高めたものと言える。

\section{2 より厚い重合皮膜の作製26), 31}

$\mathrm{Cu}$ 表面に吸着したアルカンチオール自己組織化膜の 化学修飾によって作製した二次元重合膜が非常に高い防 止効果を示すことを述べた7). さらに効果を高めるため に，テトラクロロシラン $\mathrm{SiCl}_{4}$ や 1,2 -ビス（トリクロロ シリル）エタン $\mathrm{Cl}_{3} \mathrm{Si}\left(\mathrm{CH}_{2}\right)_{2} \mathrm{SiCl}_{3}$ とオクタンジオール $\mathrm{HO}\left(\mathrm{CH}_{2}\right)_{8} \mathrm{OH}\left(\mathrm{C}_{8} \mathrm{DO}\right)$ を使って, 繰り返し化学修飾する ことで架橋構造を増し, 皮膜を厚くすることを試み た ${ }^{8), 34)}$ 。この試みは成功せず, かなり高い防止効果が得 られたものの，最も効果のあった二次元重合膜に及ぶも のはなかった。 今回, この方法を応用し, $\mathrm{Fe}$ 表面上の $\mathrm{HOMB}$ 自己組織化膜をテトラエトキシシラン $\left(\mathrm{C}_{2} \mathrm{H}_{5} \mathrm{O}\right){ }_{4} \mathrm{Si}$ (TES) と $\mathrm{C}_{8} \mathrm{DO}$ を用いて化学修飾することを試みた。

$\mathrm{Fe}$ 表面に吸着した HOMB 自己組織化膜を TES で処理 する。

$[\mathrm{Fe}]-\mathrm{C}_{6} \mathrm{H}_{4} \mathrm{CH}_{2} \mathrm{OH}+\left(\mathrm{C}_{2} \mathrm{H}_{5} \mathrm{O}\right){ }_{4} \mathrm{Si}$

$\rightarrow[\mathrm{Fe}]-\mathrm{C}_{6} \mathrm{H}_{4} \mathrm{CH}_{2} \mathrm{OSi}\left(\mathrm{OC}_{2} \mathrm{H}_{5}\right)_{3}+\mathrm{C}_{2} \mathrm{H}_{5} \mathrm{OH}$

この皮膜を $\mathrm{C}_{8} \mathrm{DO}$ と反応させ,

$[\mathrm{Fe}]-\mathrm{C}_{6} \mathrm{H}_{4} \mathrm{CH}_{2} \mathrm{OSi}\left(\mathrm{OC}_{2} \mathrm{H}_{5}\right)_{3}+\mathrm{HO}\left(\mathrm{CH}_{2}\right)_{8} \mathrm{OH}$

$\rightarrow[\mathrm{Fe}]-\mathrm{C}_{6} \mathrm{H}_{4} \mathrm{CH}_{2} \mathrm{OSi}\left(\mathrm{OC}_{2} \mathrm{H}_{5}\right)_{2} \mathrm{O}\left(\mathrm{CH}_{2}\right)_{8} \mathrm{OH}$ $+\mathrm{C}_{2} \mathrm{H}_{5} \mathrm{OH}$

水で加水分解すれば,

$x[\mathrm{Fe}]-\mathrm{C}_{6} \mathrm{H}_{4} \mathrm{CH}_{2} \mathrm{OSi}\left(\mathrm{OC}_{2} \mathrm{H}_{5}\right)_{2} \mathrm{O}\left(\mathrm{CH}_{2}\right)_{8} \mathrm{OH}+x \mathrm{H}_{2} \mathrm{O} \rightarrow$

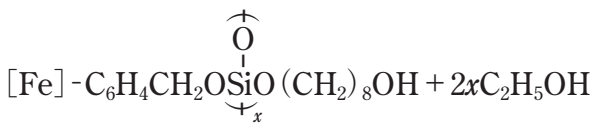

この皮膜をさらに $\mathrm{C}_{n}$ TES で化学修飾し加水分解すると,

O

$[\mathrm{Fe}]-\mathrm{C}_{6} \mathrm{H}_{4} \mathrm{CH}_{2} \mathrm{OS}_{\Psi_{x}^{\mathrm{I}}}^{\mathrm{I}}\left(\mathrm{OC}_{2} \mathrm{H}_{5}\right)_{2} \mathrm{O}\left(\mathrm{CH}_{2}\right)_{8} \mathrm{OH}+$

$$
x y \mathrm{C}_{n} \mathrm{H}_{2 n+1} \mathrm{Si}\left(\mathrm{OC}_{2} \mathrm{H}_{5}\right)_{3}+x y \mathrm{H}_{2} \mathrm{O} \rightarrow
$$

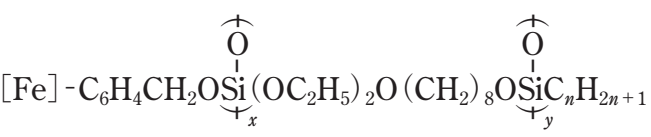

$+3 x y \mathrm{C}_{2} \mathrm{H}_{5} \mathrm{OH}$

のように, 2 つの架橋構造ができる.

皮膜の作製方法は HOMB 自己組織化膜で覆った $\mathrm{Fe}$ 電

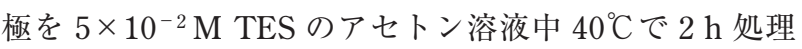

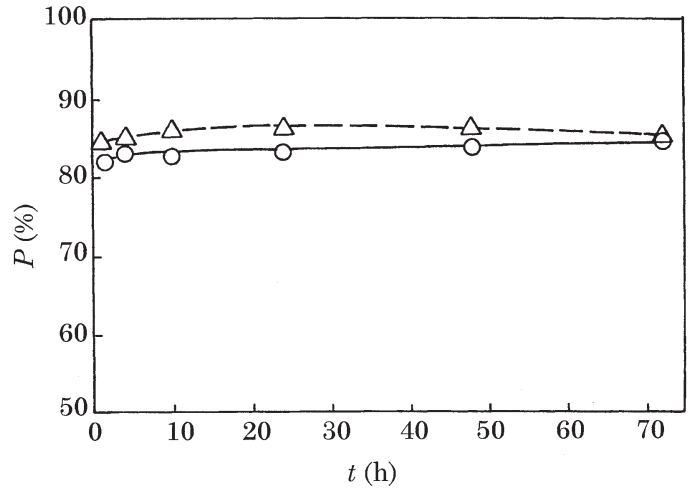

図 $11 \mathrm{TES}+\mathrm{C}_{8} \mathrm{DO}+\mathrm{C}_{8} \mathrm{TES}(\bigcirc)$ と TES $+\mathrm{C}_{8} \mathrm{DO}+\mathrm{C}_{18} \mathrm{TES}(\triangle)$ で化学修飾した HOMB 自己組織化膜の $P$ と $t$ の関係 ${ }^{31}$

し, 次に $5 \times 10^{-2} \mathrm{M} \mathrm{C}_{8} \mathrm{DO}$ のアセトン溶液中 $40^{\circ} \mathrm{C}$ で $2 \mathrm{~h}$ 浸漬した。この電極を $1 \times 10^{-2} \mathrm{M} \mathrm{H}_{2} \mathrm{O}$ アセトン溶液中で $40^{\circ} \mathrm{C}, 10 \mathrm{~min}$ 加水分解し, $\mathrm{AN}$ で洗浄後乾燥した。次に, $5 \times 10^{-2} \mathrm{M} \mathrm{C}_{8} \mathrm{TES}$ のアセトン溶液中に $40^{\circ} \mathrm{C}$ で $2 \mathrm{~h}$ または $5 \times 10^{-4} \mathrm{M} \mathrm{C}_{18}$ TES のアセトン溶液中に $40^{\circ} \mathrm{C}$ で $91 \mathrm{~h}$ 浸漬 し, $\mathrm{H}_{2} \mathrm{O}$ のアセトン溶液中で $40^{\circ} \mathrm{C} て ゙ 20 \mathrm{~min}$ 処理し, $\mathrm{AN}$ で洗浄して皮膜を完成した. 大気開放 $0.5 \mathrm{M} \mathrm{NaCl}$ 中にお けるこれらの皮膜で覆った $\mathrm{Fe}$ 電極の分極測定の結果得 られた $P$ は， $t=1.5 \mathrm{~h}$ において $\mathrm{C}_{8} \mathrm{TES}$ を用いたときが $82.1 \%, \mathrm{C}_{18}$ TES を用いたときが $84.4 \%$ で， $t=72 \mathrm{~h}$ にお いても $82 \%$ ，84\%以上を保ち，かなり高い保護性と耐久 性のある皮膜であることを示した（図 11 参照）。 $\theta$ は $70^{\circ}, 75^{\circ}$ と低く, FTIR 反射スペクトルに $\mathrm{SiOH}$ の存在が 認められた.XPS から求めた $N$ は表 1 のように増加し, より厚い皮膜を暗示した。皮膜の厚さ $d$ はそれぞれ 2.9 $\mathrm{nm}$ と $4.1 \mathrm{~nm}$ で，まだ厚さは十分ではなかった。

さらに皮膜を厚くし，架橋構造を増加させるために， TES と $\mathrm{C}_{8} \mathrm{DO}$ による化学修飾を繰り返した後に, BTESE と $\mathrm{C}_{n}$ TES で改質した。

$[\mathrm{Fe}]-\mathrm{C}_{6} \mathrm{H}_{4} \mathrm{CH}_{2} \mathrm{OSi}\left(\mathrm{OC}_{2} \mathrm{H}_{5}\right)_{2} \mathrm{O}\left(\mathrm{CH}_{2}\right)_{8} \mathrm{OH}$ $+\left(\mathrm{C}_{2} \mathrm{H}_{5} \mathrm{O}\right)_{4} \mathrm{Si}+\mathrm{HO}\left(\mathrm{CH}_{2}\right)_{8} \mathrm{OH}$

$\rightarrow[\mathrm{Fe}]-\mathrm{C}_{6} \mathrm{H}_{4} \mathrm{CH}_{2} \mathrm{OSi}\left(\mathrm{OC}_{2} \mathrm{H}_{5}\right)_{2} \mathrm{O}\left(\mathrm{CH}_{2}\right)_{8} \mathrm{O}^{-}$ $\mathrm{Si}\left(\mathrm{OC}_{2} \mathrm{H}_{5}\right)_{2} \mathrm{SiO}\left(\mathrm{CH}_{2}\right)_{8} \mathrm{OH}+2 \mathrm{C}_{2} \mathrm{H}_{5} \mathrm{OH}$

$[\mathrm{Fe}]-\mathrm{C}_{6} \mathrm{H}_{4} \mathrm{CH}_{2} \mathrm{OSi}\left(\mathrm{OC}_{2} \mathrm{H}_{5}\right)_{2} \mathrm{O}\left(\mathrm{CH}_{2}\right)_{8} \mathrm{OSi}\left(\mathrm{OC}_{2} \mathrm{H}_{5}\right)_{2}$ $\mathrm{O}\left(\mathrm{CH}_{2}\right)_{8} \mathrm{OH}+\left(\mathrm{C}_{2} \mathrm{H}_{5} \mathrm{O}\right)_{3} \mathrm{Si}\left(\mathrm{CH}_{2}\right)_{2} \mathrm{Si}\left(\mathrm{OC}_{2} \mathrm{H}_{5}\right)_{3}$

$\rightarrow[\mathrm{Fe}]-\mathrm{C}_{6} \mathrm{H}_{4} \mathrm{CH}_{2} \mathrm{OSi}\left(\mathrm{OC}_{2} \mathrm{H}_{5}\right)_{2} \mathrm{O}\left(\mathrm{CH}_{2}\right)_{8} \mathrm{OSi}\left(\mathrm{OC}_{2} \mathrm{H}_{5}\right)_{2}-$ $\mathrm{O}\left(\mathrm{CH}_{2}\right)_{8} \mathrm{OSi}\left(\mathrm{OC}_{2} \mathrm{H}_{5} \mathrm{O}\right)_{2}\left(\mathrm{CH}_{2}\right)_{2} \mathrm{Si}\left(\mathrm{OC}_{2} \mathrm{H}_{5}\right)_{3}$ $+\mathrm{C}_{2} \mathrm{H}_{5} \mathrm{OH}$

加水分解した後,

$w x y[\mathrm{Fe}]-\mathrm{C}_{6} \mathrm{H}_{4} \mathrm{CH}_{2} \mathrm{OSi}\left(\mathrm{OC}_{2} \mathrm{H}_{5}\right)_{2} \mathrm{O}\left(\mathrm{CH}_{2}\right)_{8} \mathrm{OSi}\left(\mathrm{OC}_{2} \mathrm{H}_{5}\right)_{2}$ $\mathrm{O}\left(\mathrm{CH}_{2}\right)_{8} \mathrm{OSi}\left(\mathrm{OC}_{2} \mathrm{H}_{5}\right)_{2}\left(\mathrm{CH}_{2}\right)_{2} \mathrm{Si}\left(\mathrm{OC}_{2} \mathrm{H}_{5}\right)_{3}+6 w x y \mathrm{H}_{2} \mathrm{O}$

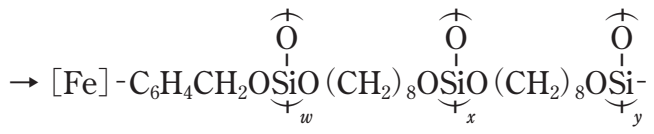

$$
\begin{aligned}
& \left(\mathrm{CH}_{2}\right)_{2} \mathrm{Si}(\mathrm{OH})_{3}+9 w x y \mathrm{C}_{2} \mathrm{H}_{5} \mathrm{OH}
\end{aligned}
$$

$\mathrm{C}_{n}$ TES で化学修飾すると 


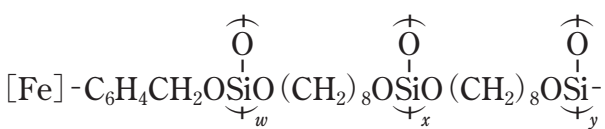
$\left(\mathrm{CH}_{2}\right)_{2} \mathrm{Si}(\mathrm{OH})_{3}+w x y z \mathrm{C}_{n} \mathrm{H}_{2 n+1} \mathrm{Si}\left(\mathrm{OC}_{2} \mathrm{H}_{5}\right)_{3} \rightarrow$

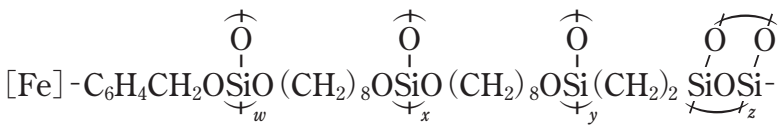

$\mathrm{C}_{n} \mathrm{H}_{2 n+1}+3 w x y z \mathrm{C}_{2} \mathrm{H}_{5} \mathrm{OH}$

のように，4つの架橋構造を持つ皮膜を作製した。この 皮膜を「2(TES $\left.+\mathrm{C}_{8} \mathrm{DO}\right)+\mathrm{BTESE}+\mathrm{C}_{n} \mathrm{TES}$ で化学修飾し た HOMB 自己組織化膜」と呼ぶことにする. XPS から 求めた $N$ はさらに増加し, 皮膜厚さの増加を示した（表 1). $\mathrm{C}_{8}$ TES を用いたときの $d$ は $4.6 \mathrm{~nm}, \mathrm{C}_{18}$ TES を用い たときの $d$ は $5.8 \mathrm{~nm}$ であった。後者の皮膜の厚さは $\mathrm{Cu}$ 表面に作製したアルカンチオール自己組織化膜の二次元 重合膜や $\mathrm{Fe}$ 不動態皮膜上に作製したカルボン酸イオン 自己組織化膜の二次元重合膜に匹敵した值であった.

これらの皮膜で覆った $\mathrm{Fe}$ 電極の分極測定を大気開放 $0.5 \mathrm{M} \mathrm{NaCl}$ 中で行った. 分極曲線から求めた $P$ を $t$ に対 して示したものが図 12 である. $\mathrm{C}_{8}$ TES を用いた皮膜は $t=1.5 \mathrm{~h}$ に扔いて $P=88.0 \%$ と高く, 時間と共に徐々に減 少したが， $t=240 \mathrm{~h}$ においても $82 \%$ を保っていた。架橋 構造と皮膜の厚さの増加によって，アノード反応だけで なく酸素の拡散を防止するカソード反応も抑制された。 $\mathrm{C}_{18}$ TES を用いた皮膜は $t=1.5 \mathrm{~h}$ において $P=85.0 \%$ とや

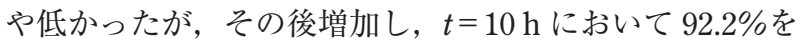
示した。 その後, 時間と共に $P$ は徐々に低下したが， $t=$ $240 \mathrm{~h}$ において $85.5 \%$ を維持していた。この耐久性の高 さは保護皮膜として非常に優れた特徵といえよう。これ らの皮膜の $\theta$ は $73^{\circ}$ と $78^{\circ}$ で, 皮膜のち密さに欠けるこ とが示された。

皮膜のち密さを増すために， $\mathrm{C}_{18} \mathrm{TES}$ を用いて作製した 皮膜をさらに $\mathrm{C}_{8} \mathrm{TES} に よ っ て$ 追加化学修飾を行った。 そ の結果の $P$ と $t$ の関係を図 12 に併せて示す. $t=1.5 \mathrm{~h}$ に おける $P$ は $90.3 \%, t=10 \mathrm{~h}$ において最大值 $93.1 \%$ を示 した. $t=240 \mathrm{~h}$ における $P$ は $86.4 \%$ と少し向上したが, 追加化学修飾によっても飛躍的な改良は見られなかっ た。繰り返し化学修飾には必ずしも反応式の通りでない 副反応を生じて, 久陥部を作る可能性を持っているので, 期待通りの高い強化が得られなかったものであろう。架

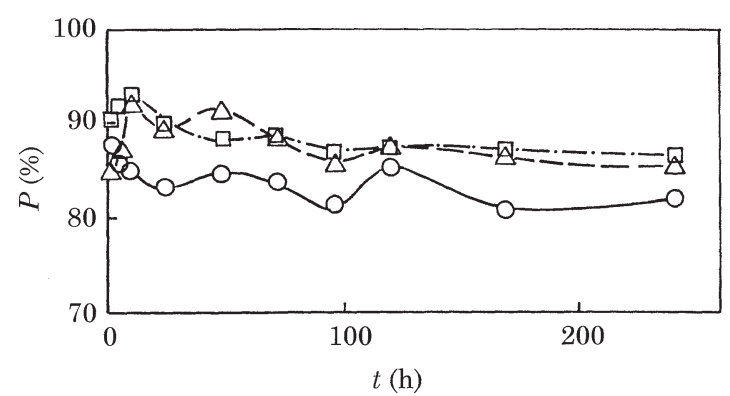

図 $122\left(\mathrm{TES}+\mathrm{C}_{8} \mathrm{DO}\right)+\mathrm{BTESE}+\mathrm{C}_{8} \mathrm{TES}(\bigcirc)$ と $2(\mathrm{TES}+$ $\left.\mathrm{C}_{8} \mathrm{DO}\right)+\mathrm{BTESE}+\mathrm{C}_{18} \mathrm{TES}(\triangle)$ で化学修飾および後者を $\mathrm{C}_{8}$ TES で追加化学修飾した $(\square)$ HOMB 自己組織化膜の $P$ と $t$ の関係 ${ }^{26)}$
橋構造や皮膜の厚さの増加による $P$ の向上にも限界があ るようである ${ }^{26)}$.

\section{7. 配位結合および共有結合によって吸着した 自己組織化膜の化学修飾によって作製した 重合体保護皮膜}

$\mathrm{Cu}$ 表面に吸着したアルカンチオールは軟らかい酸と 軟らかい塩基によって安定な配位結合を作って化学吸着 し，自己組織化膜を作る（(3)式）。この皮膜はち密で規 則正しい配列をしているために，化学修飾によって二次 元重合膜にしても欠陥部の少ない構造となり, 大気開放 $0.5 \mathrm{M} \mathrm{Na}_{2} \mathrm{SO}_{4}$ 中に扔ける $\mathrm{Cu}$ の腐食防止に優れた能力を 発揮した $(P=99.3 \%)^{1)}$. しかし，この皮膜の防止能力は 短時間（ $t=1 \mathrm{~h} ）$ では高いが，時間と共に徐々に低下し， $t=20 \mathrm{~h}$ においては $P=75 \%$ にまで減少した ${ }^{322}$. 皮膜の欠 陥部で $\mathrm{Cu}$ のアノード溶解が起こると, 表面は軟らかい 酸からやや硬い酸に変わるために, 一度脱着したアルカ ンチオールが再び吸着できないので, 腐食が進行してし まう. 図 $13 \mathrm{~A} に こ の$ 皮膜の $P$ と $t$ の関係を示す.

第 2 の化学吸着として, 不動態化した $\mathrm{Fe}$ 表面にカル ボン酸イオンが配位結合により吸着して自己組織化膜を 作る。この場合は不動態皮膜中の $\mathrm{Fe}^{3+}$ が硬い酸であるた めに, 硬い塩基であるカルボン酸イオンが安定な配位結 合を作る。この自己組織化膜を化学修飾して二次元重合 膜とすると，ホウ酸塭緩衝溶液中に打ける $\mathrm{Cl}^{-}$による不 動態皮膜破壊を完全に防止できる ${ }^{33}$. $0.1 \mathrm{M} \mathrm{NaCl}$ 中にお いて，この皮膜で覆った不動態化 $\mathrm{Fe}$ 電極は $8.5 \mathrm{~h}$ まで不 動態皮膜の破壊を防止し，それまでの間は $\mathrm{Fe}$ の腐食を 完全に防止した $(P>99.9 \%){ }^{9), 10)}$. しかし，不動態皮膜 が破壞されると局部腐食が進行し， $t=24 \mathrm{~h}$ において $P$ は77\%まで低下した（図 13B）。局部腐食によって生成 したビット内部が裸の $\mathrm{Fe}$ であり，軟らかい酸であるた め, 硬い塩基のカルボン酸イオンが再吸着できないので, 腐食を止めることができない。このように，金属表面や 酸化された金属表面に配位結合によって化学吸着した自

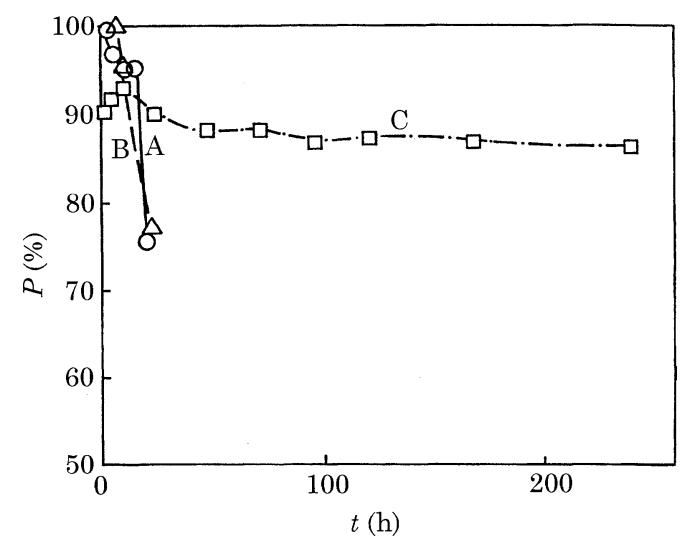

図 $130.5 \mathrm{M} \mathrm{Na}_{2} \mathrm{SO}_{4}$ 中における $\mathrm{Cu}$ 上の $\mathrm{BTCSE}+\mathrm{C}_{18} \mathrm{TCS}$ で化 学修飾した MUO 自己組織化膜 $(\mathrm{A}), 0.1 \mathrm{M} \mathrm{NaCl}$ 中にお ける不動態化 $\mathrm{Fe}$ 上の BTESE $+\mathrm{C}_{18}$ TES で化学修飾した $\mathrm{HOC}_{16} \mathrm{~A}^{-}$自己組織化膜 (B) および $0.5 \mathrm{M} \mathrm{NaCl}$ 中におけ る $2\left(\mathrm{TES}+\mathrm{C}_{8} \mathrm{DO}\right)+\mathrm{BTESE}+\mathrm{C}_{18}$ TES で化学修飾し, $\mathrm{C}_{8}$ TES で追加修飾した HOMB 自己組織化膜 $(\mathrm{C})$ の Pの 浸漬時間 $t$ 変化 
己組織化膜は短期の腐食や室内大気腐食のような緩やか な腐食に高い保護性を示すが，一度腐食が開始されると 抑制できず，長期の激しい腐食には耐えられないのが普 通である。これは HSAB 則から見ても当然である.

第 3 の化学吸着として, ジアゾニウムイオンの電解還 元によって Fe 表面に作製したベンゼン誘導体の自己組 織化膜のような, 共有結合による吸着がある. この吸着 結合は強く, 長時間の腐食に対する耐久性があるが, 自 己組織化膜がち密さに久けるので吸着分子間に酸化物を 作りやすく，架橋構造の作製や皮膜の厚さを十分なもの にするために, 化学修飾に種々の改良が加えられた。し かし，配位結合によって作られた自己組織化膜に比べて 疎な配列が弱点となり, 最大值でも $P$ が $94 \%$ に達しなか った。一方, 長時間腐食環境に曝された場合の耐久性は 他の自己組織化膜にない特徵で, 保護皮膜の性能として 高い評価が得られると考えている. 図 13C が示すように, $t=240 \mathrm{~h}$ においても $86 \%$ 以上の $P$ が得られている.この 皮膜をさらに改質して, よりち密な, ある程度厚い高分 子皮膜とすることができれば，激しい腐食環境において も優れた保護皮膜になり得るかもしれない。

\section{8. おわりに}

この一連の解説シリーズの最初に述べたように, 化学 吸着によって得られたち密で規則正しい配列の自己組織 化膜を化学修飾し, 架橋構造によって皮膜を強固にし, またアルキル鎖の延長によって皮膜を厚くすることで， 水溶液中や大気中の腐食を防止することを目的として研 究してきた. 水溶液中の短期間の腐食や室内大気腐食の ような緩やかな腐食に対しては十分な腐食の防止が達成 できたが，長時間の激しい腐食環境には耐えられなかっ た。この皮膜の欠点をカバーするには, 強い共有結合に よって化学吸着する自己組織化膜の利用が優れている が，高い防止効果を得ることに困難さがあった。また， 不動態皮膜上に作られた自己組織化膜についても， $\mathrm{Cl}^{-}$ のような激しい破壊を起こす腐食環境でなければ, 長時 間の不動態皮膜破壊と腐食の防止ができることが認めら れている ${ }^{34)}$. 腐食反応の激しさを考慮に入れれば， $\mathrm{nm}$ オーダーの厚さで腐食を完全に防止することが不可能で はないというのがこの一連の研究における一つの結論で ある。

\section{参 考 文 献}

1) K. Aramaki, Zairyo-to-Kankyo, 56, 243 (2007).

2) K. Aramaki, Zairyo-to-Kankyo, 56, 292 (2007).

3) K. Aramaki, Zairyo-to-Kankyo, 45, 674 (1996).

4) K. Aramaki, Zairyo-to-Kankyo, 46, 342 (1997).

5) K. Aramaki, Zairyo-to-Kankyo, 46, 748 (1997).

6) K. Aramaki, Zairyo-to-Kankyo, 56, 542 (2007).

7) K. Aramaki, Zairyo-to-Kankyo, 51, 136 (2002).

8) K. Aramaki, Zairyo-to-Kankyo, 52, 332 (2003)

9) K. Aramaki, Zairyo-to-Kankyo, 55, 224 (2006).

10) K. Aramaki and T. Shimura, Corros. Sci., 47, 2901 (2005).

11) Y.-C. Liu and R. L. McCreery, J. Am. Chem. Soc., 117, 11254 (1995)

12) R. Allongue, M. Delamar, B. Desbat, O. Fagebaume, R. Hitmi, J. Pinson and J.-M. Savéanat, J. Am. Chem. Soc., 119, 201 (1997).

13) Y.-C. Liu and R. L. McCreery, Anal. Chem., 69, 2091 (1997).

14) J. K. Kariuki and M. T. McDermott, Langmuir, 15, 6534 (1999).

15) A. Adenier, M.-C. Bernard, M. M. Chehimi, E. CabetDeliry, B. Desbat, O. Fagebaume, J. Pinson and F. Podvorica, J. Am. Chem. Soc., 123, 4541 (2001).

16) A. Chaussé, M. M. Chehimi, N. Karsi, J. Pinson, F. Podvorica and C. Vautrin-Ul, Chem. Mater. 14, 392 (2002).

17) A. Adenier, E. Cabet-Deliry, T. Lalot, J. Pinson and F. Podvorica, Chem. Mater., 14, 4576 (2002).

18) M.-C. Bernard, A. Chaussé, E. Cabet-Deliry, M. M. Chehimi, J. Pinson, F. Podvorica and C. Vautrin-Ul, Chem. Mater., 15, 3450 (2003).

19) K. Boukerma, M. M. Chehimi, J. Pinson and C. Blomfield, Langmuir, 19, 6333 (2003).

20) B. L. Hurley and R. L. McCreery, J. Electrochem. Soc., 151, B252 (2004).

21) A. Adenier, E. Cabet-Deliry, A. Chaussé, S. Griveau, F. Mercier, J. Pinson and C. Vautrin-Ul, Chem. Mater., 17, 491 (2005).

22) C. Combellas, M. Delamar, F. Kanoufi, J. Pinson and F. Podvorica, Chem. Mater., 17, 3968 (2005).

23) T. Shimura and K. Aramaki, Corros. Sci., 48, 3784 (2006).

24) T. Shimura and K. Aramaki, Corros. Sci., 49, 1378 (2007).

25) K. Aramaki and T. Shimura, Corros. Sci., 46, 313 (2004).

26) T. Shimura and K. Aramaki, Corros. Sci., 50, 2407 (2008).

27) K. Aramaki and T. Shimura, Proc. JSCE Materials and Environments 2008, p. 323, Jap. Soc. Corros. Eng. (2008).

28) T. Shimura and K. Aramaki, Corros. Sci., 49, 3742 (2007).

29) T. Shimura and K. Aramaki, Corros. Sci., 50, 292 (2008).

30) T. Shimura and K. Aramaki, Corros. Sci., 50, 596 (2008).

31) T. Shimura and K. Aramaki, Corros. Sci., 50, 1393 (2008).

32) R. Haneda and K. Aramaki, J. Electrochem. Soc., 145, 1856 (1998).

33) K. Aramaki and T. Shimura, Corros. Sci., 48, 209 (2006).

34) K. Aramaki and T. Shimura, Corros. Sci., 50, 3542 (2008).

（2008 年 7 月 4 日受理）

\section{要旨}

鉄-炭素共有結合によって Fe 表面に吸着した $p$-ヒドロキシメチルベンゼン自己組織化膜 $(\mathrm{SAM})$ をジア ゾニウムイオンの電解還元によって作製した。アルキルエトキシシラン類を用いた化学修飾によって，こ の SAM の超薄重合皮膜を $\mathrm{Fe}$ 表面に作製した. $\mathrm{Fe}$ 腐食に対する皮膜の防止能力を大気開放 $0.5 \mathrm{M} \mathrm{NaCl}$ 溶 液中で評価した。強い吸着結合の生成のために, 皮膜の高い腐食防止作用が溶液中の長時間浸漬後に得ら れた.

キーワード＼cjkstart超薄保護皮膜, 自己組織化膜, $p$-ヒドロキシメチルベンゼン, 鉄, 共有結合吸着, 化学 修飾，高分子皮膜 